\title{
Teaching Social Interaction Competence to Technical University Students
}

\author{
O. N. Rodina \\ Department of Foreign Languages \\ Industrial University of Tyumen \\ Tyumen, Russia \\ o_rodina2605@mail.ru
}

\author{
O. A. Selivanova \\ Department of General and Social Pedagogy \\ Tyumen State University \\ Tyumen, Russia \\ towerred1966d@mail.ru
}

\begin{abstract}
The authors prove the necessity of forming students' individual personality traits, skills and abilities to improve the efficiency of interaction in the social sphere. The article proposes an interpretation of the essence and the structure of social interaction competence of technical university students. In the Industrial University of Tyumen in 2016, a research was held for defining the first year students' adaptation behaviors ("active response" behavior and "inactive response" behavior) and a manifestation level of students' social interaction competence. The 3 groups of the personal determinants (intellectual skills, volitional skills, and social attitudes) considered to facilitate a high level of the social interaction competence formation were revealed and characterized. Based on the theoretical and practical background, the key directions are given for developing the students' social interaction competence by means of educational activities in a technical university. It is emphasized that within a technical university, such systematic and purposeful activities ensure to educate a person ready for an effective social interaction.
\end{abstract}

Keywords-social interaction, social interaction competence, personal determinants, intellectual skills, volitional skills, social attitudes, academic activity

\section{INTRODUCTION}

Employers express some dissatisfaction with recent graduates. The university graduate's personality is greatly increasing in the hiring process. Besides solid theoretical and practical knowledge in the field of specialization, they seek graduates having an ability to communicate, to work in a team and to regulate interpersonal relationships with co-workers, and collaborators [1]; strong skills in the area of human relations, communication, and personal skills [2]. The socialization of a young person occurs under new social and cultural factors. Actually there is a tendency of excessive concentration of individuals on themselves, depersonalization of relations between people, preference for "virtual" communication in social networks to live communication in the situations of social interaction. Similar trends are also present in the educational environment of higher education. On the one hand, an educational methodology based on class lectures results in students being completely passive during their education. On the other hand, an introduction of information technologies hinders the development of interpersonal skills that the employers value. The educational environment is built on computer interaction technologies (virtual libraries, electronic books, complete computerized courses, and excessive distribution of distance learning courses, etc.). Moreover, during the educational process, a significant part of class activities is concentrated on the "student - computer" interaction. It influences the essence, the content and the effectiveness of face-to-face communication. In the student environment, it might be observed that the students cannot organise effective verbal interpersonal communication, perform joint activities and cooperate, overcome nebulous problems. These problems being unresolved are likely to appear in the practical professional postgraduate activity, significantly reducing its effectiveness. In technical universities, these problems are sure to be more acute due to the specifics of technical subjects. The abovementioned stresses out that the students must be taught through interactive learning tasks (role-playing, reports, presentations, etc.) in order to form personal, interpersonal qualities, and skills that enhance the effectiveness of social interaction. Researchers highlight the following backgrounds for effective social interaction:

- personal characteristics including axiological, cognitive, and personality components that determine the system of social relations, social and cultural values oriented to the interaction of an individual with the society [3];

- a set of practically assimilated value orientations, knowledge, ways of building mutual relations with people and social groups to constructively carry out joint activities and communication in different life situations [4].

A competence-based approach in education helps to study in depth the phenomenon of social interaction. A Russian scientist, I.A. Zimnyaya, defined the concept of social interaction competence as one of the main social competences, and as an ability to establish mutual understanding, avoid conflicts, create a climate of confidence [5]. There are many studies devoted to the development of social competence in young children [6] and in teens [7]. Social competence is seen as a factor in reducing behavioral problems [8]. A significant part of studies reveals the specifics of social competence formation in future engineers. The authors especially emphasize necessity for developing skills to work in a team, skills to solve nebulous problems, work in interdisciplinary groups and environments, and communicate effectively 
knowledge to colleagues and clients with diverse backgrounds [9; 10].

Analysis of modern pedagogical studies shows the growing interest in the problem of social competence as a result of education. Significant numbers of Russian studies are devoted to the training process. Researchers stress out the need for formation of social interaction competence in future engineers. They underline that social interaction competence (social competence) is of great practical value in everyday and professional life.

Literature review shows that there is no unique understanding of two basic concepts such as a "competence" and a "competency". A competence is usually understood as an actual integral life-formed and knowledge-based personal quality performed in real-life situations [3]. "The concept of competence is a key word in education ...used in developing, training, and educating students in such way that they are able to meet the demands of work" [11]. A competency is often identified as a semantic content of competence [12], and as knowledge, skills and experience of an individual [13].

\section{Research Hypothesis}

The formation of social interaction competence of technical university students will be more successful if the pedagogical stuff takes into consideration the theoretical results on the students' social interaction competence obtained in this research, namely its essence, its content, its characteristics, and the personal determinants facilitating this process. It will be more productive if necessary pedagogical conditions are implemented into the educational process. Firstly, the pedagogical process should be organized as a joint activity between the students and the teachers. Secondly, one should use the potential of the humanitarian disciplines (the first language, the second language, philosophy, etc.), creating a large number of interpersonal links (a teacher - a student, a student - a student, a student - a small group of students) to form skills to regulate interpersonal interaction. Thirdly, one should include a set of social situations aimed at personality development that require effective joint activities and cooperation based on differences in opinions, desires, intentions, goals, motives, attitudes, and, different educational and life experiences. Fourthly, the content and means of pedagogical assistance should contribute to the enrichment of students' experience and form a skill to effectively prevent and overcome emerging difficulties. Fifthly, a system of training activities should include different tasks creating interpersonal communication and making students to communicate thoughts, feelings, and ideas to justify their position.

\section{FINDINGS}

\section{A. Essence and Content of Students' Social Interaction Competence}

In the present paper, the students' social interaction competence is understood as an integral characteristic of a personality (a set of personal determinants) that manifests itself in interpersonal situations, in joint activities for establishing mutual understanding, avoiding conflicts and creating an atmosphere of confidence. The students' social interaction competence can be characterized by 4 components such as cognitive, motivational, axiological, behavioral, and regulatory. The content of the cognitive component includes a system of knowledge such as norms of behavior, constructive interaction ways, and socially acceptable ways of selfaffirmation in educational activities and in the professional sphere. The content of the motivational component includes internal and external motives related to an intention to establish social interaction, mutual assistance, cooperation, and partnership relations. The content of the axiological component includes social axiological orientations and a system of personal meanings among them. There is recognition of a leading role of individuals in the progress, the importance of mutual understanding between people (acceptance of motives, values and attitudes of other people), the importance of mutual assistance (an intention to provide assistance), the importance of professional and collaborative relations, partnerships (an intention to find an individual approach to people). The content of the behavioral component is filled by skills to recognize, regulate, control, express emotions (empathy, tolerance, etc.), skills to use behavior tactics in standard and non-standard situations of interpersonal interaction, an intention to participate as a member of the team. The content of the regulatory component is filled by a skill to analyze and evaluate the results of interaction, rethink and, on this basis, adjust one's actions and other people's actions, a skill to find innovative ways and creative ideas in solving problems in the field of social interaction [14].

\section{B. Personal Determinants Leading to a High Level of Social Interaction Competence}

This study identified the 15 personal determinants considered to facilitate a high level of the social interaction competence formation, which are intellectual skills, volitional skills, and social attitudes. Intellectual skills include a perception fluency (a skill to generate many ideas), a flexibility of mind (a skill to see a problem from different angles), and an originality (a skill to make non-trivial ideas). Volitional skills include an initiative in establishing contacts, resoluteness in interaction, self-management. Social attitudes include an intention to work in a team, an intention for cooperation, a breadth of mind (a skill to understand and accept someone else's point of view), tolerance (to the views and opinions of others), empathy, openness to communication, an intention to offer help, and responsibility for people.

\section{METHODS AND RESULTS}

\section{A. Participants}

A longitudinal study was carried out with 160 first-year university students aged from 18 to 19 (65 females and 65 males). They were of diverse social status. Some of them were from profession-oriented secondary schools and others were from secondary schools. They were representatives of the town and countryside population, having some work experience and none experience before entering the university. 
To assess personal qualities influencing interpersonal relationships, tree questionnaires were used. In order to assess the students' communicative level, Rjahovskij's Questionnaire was used. Each item was rated on a three-point scale (1-“yes", 2 - "no", 3 - "sometimes"). Obtained results were added. The communicative level of the participants was determined by the classifier. Some questions from the questionnaire were: Are you more likely to express your point of view in a written or verbal form? Are you afraid of participating in a commission for the consideration of conflict situations? ... [15].

T. Liri's technique was used to diagnose individual properties. It consists of 128 judgments to reveal the prevailing type of relationship with people in self-esteem and mutual appreciation.

K. Thomas's questionnaire was used for identification of the leading strategy in the conflict [16].

\section{B. "Active Response" Behavior}

Data on the students' social interactions were collected by testing and observation over a 3-month adaptation period in the university. Observation data were obtained during classroom activities. The study showed that during the first months of the training course, the first-year students chose between two kinds of personal interaction. The first was "active response" behavior (35\% of the respondents). Students choosing this behavior quickly integrated into a new social environment.During the educational process, they actively contacted with teachers; they creatively did their homework. They agreed willingly to make a report, a presentation in front of the group. They participated willingly in teamwork. They demonstrated friendliness, empathy, politeness. They were cheerful and open to communication with other people. They did not have the difficulty in seeking help and they willingly offered help to others. They took an initiative to establish contacts. They willingly participated in debates, stated and defended their point of view on any issue.

As the study showed, this behavior was largely due to a set of developed skills (personal qualities, thinking skills, social skills, interpersonal competencies) of participants. In addition, it was established that there were a significant number of students with a successful previous social experience (an active position of the student in school and extracurricular activities as volunteering, etc.). Obviously, this group had a significant potential for the social interaction competence development in the workplace. The study showed that the social interaction competence was formed in this group of respondents at a sufficient level. They quickly integrated into a new social environment in the academic process. They participated willingly as members of team in joint activities.

\section{C. "Inactive Response" Behavior}

The second group of the respondents could be characterized by "inactive response" behavior $(65 \%$ of the respondents). Not having a broad picture about the university environment (rules and norms of interaction, specifics of a new social status, communicative area, etc.), this group preferred not to show excessive activity. They had difficulty in establishing contacts with teachers and group mates. They were lack of imagination for doing homework. They did not show any initiative to integrate into the curriculum and extracurricular activities. They felt awkward, confused to make a presentation, a report in front of the group. They showed no desire to participate in collective work. The desire to communicate with other people was limited. They did not express their opinions during the debates, showing the conformal type of behavior. They were not willing to seek help. The need for new contacts disturbed their emotional states.

The identified specific behavior was due to the lack of success or negative previous personal experience in the social life (being bullied at school etc.), a low social status, psychological pressure experience for excessive activity behavior on the part of parents and teachers, etc.

\section{Manifestation of Students' Personal Determinants}

To define a manifestation degree of the students' personal determinants, the authors used a three-position scale of answers to the question: "To what extent do you have the following personal qualities manifested in the sphere of social interaction?" 1) sufficient, 2) low 3) absent.

Analysis of the results (Table 1) showed that the majority of students $(94 \%)$ demonstrated friendliness in relationships, and an intention to find mutual understanding with others. Only $6 \%$ of respondents stated that this quality was of less extent than they would like. Among the respondents, no one answered that they did not have this quality. The low manifestation degree of such volitional personal quality as "self-management" (30\%) indicated that the respondents were direct and capable of self-disclosure in communication (confirmed by the fact that openness to communication was expressed by $70 \%$ ), but also they did not control the manifestation of their emotions and did not always know where and how to behave. Despite the fact that the respondents expressed friendliness in the relationship, only 37 $\%$ showed an initiative to establish contacts, and $57 \%$ had this quality less than they would like. It should be noted that intellectual qualities were represented in the least extent in the structure of a personality. "An originality" when solving problems arising in joint activity was shown by $41 \%$, "a flexibility of mind" - $38 \%$, "a fluency of perception" - only by $18 \%$. That confirmed the fact that respondents did not have sufficient knowledge, skills, and rich experience of joint activities, and social interaction due to social status, age. Leading positions were occupied by "an intention for cooperation" (74\%), "openness to communication" (70 \%), "an intention to work in a team" (66\%), which are necessary conditions for joint activity of any business.

The hierarchy of the personality determinants (Table 1) reflects the specifics of the students' social interaction competence. 


\section{DISCUSSIONS AND CONCLUSION}

The process of social interaction competence formation of technical university students should be based on the didactics principles:

- a principle of cooperation and mutual understanding in which the student is treated as an active subject of the pedagogical process;

- a principle of accounting for personal characteristics and actual students' skills (it includes revealing the peculiarities of perceptual, mental, emotional and personal properties that determine the success of the student's educational activity and the definition of its nearest development zone).

- a principle of educative nature (the educational process should be oriented to personal, interpersonal skills development).

- a principle of professional oriented activities;

- a principle of theory and practice uniqueness (the main feature of this principle is that the students first of all should understand that theory is important in the life of a person when they know how to apply the acquired knowledge to solve practical problems that they face in an educational process and will face in a professional life).

TABLE 1. A THREE-POSITION SCALE OF ANSWERS TO THE QUESTION: "TO WHAT EXTENT DO YOU HAVE THE FOLLOWING PERSONAL QUALITIES MANIFESTED IN THE SPHERE OF SOCIAL INTERACTION?'

\begin{tabular}{|c|c|c|c|}
\hline \multirow{2}{*}{$\begin{array}{c}\text { Personal } \\
\text { determinants }\end{array}$} & \multicolumn{3}{|c|}{ Manifestation Index, \% } \\
\hline & Sufficient & Low & Absent \\
\hline friendliness & 94 & 6 & - \\
\hline $\begin{array}{l}\text { an intention for } \\
\text { cooperation }\end{array}$ & 74 & 26 & - \\
\hline $\begin{array}{l}\text { openness to } \\
\text { communication }\end{array}$ & 70 & 17 & 13 \\
\hline $\begin{array}{l}\text { an intention to } \\
\text { work in a team }\end{array}$ & 66 & 25 & 9 \\
\hline $\begin{array}{l}\text { responsibility for } \\
\text { people }\end{array}$ & 64 & 32 & 4 \\
\hline $\begin{array}{l}\text { an intention to } \\
\text { offer help }\end{array}$ & 60 & 40 & - \\
\hline empathy & 59 & 37 & 4 \\
\hline $\begin{array}{l}\text { a breadth of } \\
\text { mind }\end{array}$ & 55 & 39 & 6 \\
\hline tolerance & 54 & 40 & 6 \\
\hline $\begin{array}{l}\text { resoluteness in } \\
\text { interaction }\end{array}$ & 49 & 45 & 6 \\
\hline an originality & 41 & 53 & 6 \\
\hline $\begin{array}{l}\text { a flexibility of } \\
\text { mind }\end{array}$ & 38 & 46 & 16 \\
\hline $\begin{array}{l}\text { an initiative in } \\
\text { establishing } \\
\text { contacts }\end{array}$ & 37 & 57 & 6 \\
\hline self-management & 30 & 70 & - \\
\hline $\begin{array}{l}\text { a perception } \\
\text { fluency }\end{array}$ & 18 & 62 & 20 \\
\hline
\end{tabular}

Systematic and purposeful activities based on these principles promote the formation of personal qualities, social attitudes, skills facilitating the formation of students' social interaction competence. Besides, educators can train students so that they would be ready not only for self-fulfillment but also ready to live and work in a team, and to have not only rights, but also duties for other people and the society.

\section{References}

[1] J. Hernández-March , M. Martín del Peso, S. Leguey , "Graduates' Skills and Higher Education: The employers' perspective," Tertiary Education and Management, vol.15:1, pp. 1-16, 2009.

[2] M. Ellis, E. Kisling, and R. G.Hackworth, "Teaching Soft Skills Employyers need ," Community College Journal of Reseach and Practice, vol. 38, pp 433-435, 2014.

[3] G.F. Arstangaleeva, "Formation of culture of social interaction of the student in the open educational space of the college," Phd thesis, Orenburg, 26 p., 2011. (in Russian).

[4] E.V. Kharitonova, "Formation of experience of social interaction of a teenager in the establishment of additional education for children," Phd thesis, Orenburg, 26 p., 2011. (in Russian).

[5] I.A. Zimnjaja, "Key competencies of a new paradigm of education result," Higher education today, No. 5, pp. 34-42,2003. (in Russian).

[6] J. R. Bullock, "Encouraging the development of social competence in young children," Early Child Development and Care, vol. 37:1, pp. 4754, 1988.

[7] A. Lee , B. L. Hankin, R. J. Mermelstein, 'Perceived Social Competence, Negative

Social Interactions, and Negative Cognitive Style Predict Depressive Symptoms During Adolescence," Journal of Clinical Child \& Adolescent Psychology, vol. 39:5, pp. 603-615, 2010.

[8] J. H. Langeveld , K. K. Gundersen, F. Svartdal, "Social Competence as a Mediating Factor in Reduction of Behavioral Problems," Scandinavian Journal of Educational Research, vol. 56:4, pp. 381-399, 2012.

[9] L. Backa, M. Wihersaari, "Future Engineering Education: What Competences are Energy Companies Looking for when Recruiting Graduates with a Master of Science (Technology) Degree?," Engineering Education, vol. 9:1, pp. 2-17, 2014.

[10] J. Foster, G. Yaoyuneyong, "Teaching innovation: equipping students to overcome real-world challenges," Higher Education Pedagogies, vol. 1:1, pp. 42-56, 2016.

[11] A. Stoof, R. L.Martens, J.V.Jeroen,V. Merrienboer, Th. J. Bastiaens, "The boundary approach of competence: a consractive aid for understanding and using the concept of competence," Human Resource Development Review, vol. 1:3, pp. 345-365, 2002.

[12] A.N. Dahin, "Competency and competence: how many of them do a Russian student have?," Public education, vol. 4, 2004. (in Russian).

[13] F.F. Zeer, Competence approach to education," Education and Science, vol. 3, pp. 27- 40, 2005 (In Russian).

[14] O.N. Rodina, O. A. Selivanjva, "Technical college students' social competence formation during academic activity," Humanitates, vol. 2: 3, 182-192, 2016. (in Russian).

[15] E.I.Rogov, Handbook of practical psychologist: The work of a psychologist with adults. Correction techniques and exercises. - 2 nd Moscow: VLADOS, 480 , 52-55, 1999. (in Russian).

[16] V.P.Pugachev, Tests, business games, trainings in personnel management: training. For university students, M.: Aspect Press, 2003, 283 p. (in Russian). 